\title{
Non-invasive Methods of Computer Vision in the Posture Evaluation of Adolescent
}

\section{Idiopathic Scoliosis:}

\section{A Systematic Review}

Rozilene Maria C. Aroeira, MSc. ${ }^{a}$; Estevam B. de Las Casas, Ph.D. ${ }^{\text {; }}$; Antônio Eustáquio M. Pertence, Ph.D. ${ }^{\text {; }}$ Marcelo Greco Ph.D. ${ }^{\text {; }}$ João Manuel R. S. Tavares Ph.D. ${ }^{\mathrm{e}}$

a Physiotherapist, PhD student, Departamento de Engenharia de Estruturas, Escola de Engenharia, Universidade Federal de Minas Gerais, Av. Antônio Carlos, 6627, Pampulha _ CEP: 31270-901, Belo Horizonte, MG, Brazil, Tel. 5531 34093590. e-mail: rozecota@hotmail.com

${ }^{b}$ Chief of Biomechanical Service, Departamento de Engenharia de Estruturas, Escola de Engenharia, Universidade Federal de Minas Gerais, Av. Antônio Carlos, 6627, Pampulha _ CEP: 31270-901, Belo Horizonte, MG, Brazil, Tel. 5531 34093590. e-mail: estevam.lascasas@gmail.com

${ }^{\mathrm{c}}$ Professor, Departamento de Engenharia Mecânica, Escola de Engenharia, Universidade Federal de Minas Gerais, Brazil. e-mail: pertence@demec.ufmg.br

d Professor, Departamento de Engenharia de Estruturas, Escola de Engenharia, Universidade Federal de Minas Gerais, Av. Antônio Carlos, 6627, Pampulha _ CEP: 31270-901, Belo Horizonte, MG, Brazil, Tel. 553134093590. e-mail: greco@dees.ufmg.br

e Professor, Instituto de Ciências e Inovação em Engenharia Mecânica e Engenharia Industrial, Departamento de Engenharia Mecânica, Faculdade de Engenharia, Universidade do Porto, Portugal. e-mail: tavares@fe.up.pt

\section{Name and Address for Correspondence:}

Prof. João Manuel R. S. Tavares

Faculdade de Engenharia da Universidade do Porto (FEUP)

Departamento de Engenharia Mecânica (DEMec)

Rua Dr. Roberto Frias, s/n

4200-465 PORTO, PORTUGAL

Telf.: +31522 5081487, Fax: +315225081445

Email: tavares@fe.up.pt - Url:www.fe.up.pt/ tavares 


\section{Non-invasive Methods of Computer Vision in the Posture Evaluation of Adolescent}

Idiopathic Scoliosis:

A Systematic Review

\section{SUMMARY}

Purpose: Reviewing techniques for non-invasive postural evaluation of adolescent idiopathic scoliosis (AIS) based on information extraction from images based on computer methods. Methods: The Scopus, Web of Science, MEDLINE, ScieLo and PubMed databases were used, for the period 2011-2015. Results: 131 articles were found based on keyword of which 15 articles met the established eligibility criteria. Of these, 4 were based on photogrammetry, and 11 based on laser, structured light, ultrasound, and Moiré projection. In these studies, the methodological quality varied from low to high. Conclusions: The findings indicated diversity in methodologies; 14/15 articles reviewed were limited to the evaluation of the topography of the posterior back. A study, using twodimensional photogrammetry, presented a whole body postural evaluation. As the asymmetry in AIS can be extended to the whole body, more attention should be given to develop full body assessment techniques to provide important additional data to aid in treatment decisions.

Keywords: Body posture; Evaluation; Adolescent idiopathic scoliosis; Computational methods; Imaging 


\section{$\underline{\text { INTRODUCTION }}$}

The vertebral spine is the main structure of loading and load distribution in the human body (Panagiotopoulou 2009), which under pathological or dysfunctional conditions, may be subjected to adaptive alterations in search of equilibrium (Stemper 2010). The basic condition for correct posture is minimum stress; however, if this stress is increased for some reason, adaptive postural configurations can arise (Filipovic \& Ciliga 2010). Adolescent idiopathic scoliosis (AIS) is a highly complex spinal disease, whose main feature is an impairment of the spinal structure generating important changes in load distribution. It is considered the most common vertebral deformity in the world. It affects $2 \%$ to $4 \%$ of young individuals, predominantly female, during the process of bone maturation (Driscoll et al 2009, Komeili et al 2014, Han et al 2015). The main characteristic of AIS is a three-dimensional (3D) alteration in the alignment of the vertebral segments, which may lead to biomechanical changes along the entire corporal structure. The position of a vertebral segment affects other segments as well as the whole body posture (Smidt et al 1984). It is not rare and has great esthetical impact, leading the young individuals to serious physical and psychosocial disturbances (Han et al 2015). Cranial and pelvic adaptations are commonly found in cases of AIS. In a review study (Saccucci et al 2011), the authors concluded that there is plausible evidence for an increased prevalence of unilateral Angle Class II malocclusions associated with scoliosis, and an increased risk of lateral crossbite and midline deviation in children affected by scoliosis. In addition, associations found between a reduced range of lateral movements and scoliosis are convincing.

The causes of AIS have not yet been well established. In any case, it is known that, regardless of the reason causing the deformation, its progress is a question of 
biomechanics (Van der Plaats et al 2007). According to Kowalski et al (2014), monitoring tests of body posture in schoolchildren revealed that $50-60 \%$ of adolescent schoolchildren had postural abnormalities, with $10 \%$ of this group at risk of progressive spine deformity. According to Cheung et al (2015), early screening and observation of scoliosis can apparently mitigate the surgical risk. Furthermore, a timely diagnosis of AIS prevents an excessive progression to a pathological postural adaptation.

Since the 1940's, the X-ray exam, using the Cobb angle, has been considered the gold standard in the diagnosis and follow-up of the aforementioned vertebral alteration in youths (Komeili et al 2014). Based on radiological evaluations, only $10 \%$ of the scoliosis cases will require some type of treatment. In routine medical conduct, a scoliosis with a Cobb angle from $10^{\circ}$ to $20-25^{\circ}$ is considered "light", and requires no treatment but only radiological follow-up to monitor the evolution of the curve; an angle from $25^{\circ}$ to $40-45^{\circ}$ is considered "moderate", and conservative treatment using a brace is recommended; and an angle greater than $45-50^{\circ}$ is considered to be "serious", and surgical intervention is indicated for vertebral correction and stabilization (Bettany-Saltikov et al 2012, Komeili et al 2015). Despite its high relevance in the diagnosis of the deformity, the use of this exam has suffered increasing criticism. Many studies have presented (Enríquez et al 2014) and demonstrated the deleterious effects on the young from the innumerous sessions of ionizing radiation to which they are subjected for the scoliosis control (Levy et al 1994, Goldberg et al 1998, Doody et al 2000, Bone \& Hsieh 2000, Ron 2003, Berrington de Gonzales \& Darby 2004). Additionally, the X-ray exam, being mainly an exam of pathological diagnosis, is not an adequate tool for the evaluation of the biomechanical dysfunction related to the unbalance of vertebral curves, which is explained by kinetic and kinematic variables. Complementary postural exams, which permit the investigation 
of this postural asymmetries, do not constitute as common practice in the monitoring and follow-up of scoliosis. Postural assessment is a standard and essential component of examining individuals with neuromusculoskeletal disorders (Brink et al 2011). Similar values of Cobb angles may present very distinct whole postural asymmetries, and significant asymmetries may be associated to low Cobb angles. Hence, most cases of scoliosis are classified as "light" and are considered not eligible for medical treatment, even when being associated with multiple asymmetries in several body segments. Han et al (2015), in a study on the quality of life of post-operative patients with scoliosis, stated that the radiological exam should no longer be the only therapeutic indicator in AIS, and that new systems of evaluation should be developed focused on the quality of life of the patients.

\section{$\underline{\text { Posture and posture asymmetries }}$}

In 1947, the American Academy of Orthopaedic Surgeons defined posture as "... the relative arrangement of parts of the body, where muscular and skeletal equilibrium is responsible for adequate positioning and muscular efficiency" (Subasi 2014). The position of one segment affects other segments and the overall posture (Magee 1992). Corporal plane asymmetries are frequently associated to inadequate loading of the musculoskeletal structure, and in many cases may represent a risk of pain and lesions (Singla \& Vegar 2014, Singla \& Vegar 2015). Idiopathic scoliosis is characterized by the presence of significant asymmetries in the structure of the trunk, in addition to asymmetries that extend to the entire body. However, a well-defined pattern for these compensatory misalignments related to scoliosis curves has not been established yet.

Postural evaluation based on the subjective method of visual inspection is still a 
common procedure during medical consultations (Brink et al 2011). The most widely used protocol recommends examination in the natural biped position, in which the frontal anterior and posterior planes, as well as the right and left sagittal planes are evaluated from head to foot (Rosário 2014). The majority of analysis methods available in clinical examination are non-invasive, employing low-cost technologies and no computer, such as visual inspection, plumb line, symmetrograph, goniometer, scoliometer, flexicurve, inclinometer, kyphometer (Brink et al 2011, Singla \& Vegar 2014), and computational low cost as two-dimensional (2D) photogrammetry (Ricieri \& Filho 2009). Other higher cost technologies such as SpinalMouse ${ }^{\circledR}$ (Zsidai \& Kocsis 2003), Ortelius800 ${ }^{\mathrm{TM}}$ (Ovadia et al 2007), and Body and Medical 3D Laser Scanner are available. The analysis methods based on X-ray and computerized tomography are considered invasive.

In the last twenty years, a great scientific effort has been dedicated to the development of non-invasive methods for the evaluation of the spinal deformity, with various noninvasive instrumental techniques being proposed to surpass the limitations of the manual methods and reduce the number of radiological examinations used in the monitoring of these deformities.

\section{Computer vision based methods}

The area of computer vision, also known as artificial vision, emerged from the human search to artificially reproduce functions of the human, and other animals. This scientific field is concerned with the development of computer theories and methods for automatic extraction of useful information from images (Tavares 1995). The analysis of human superficial anatomy through visual information has also been an area of active research in the computer vision domain (Chen et al 2013). From the point of view of static postural 
evaluation, surface topography is the most widely used method to investigate human surface anatomy (Komeili et al 2015). This type of analysis originated with photographic images, and gained more attention during the 90's thanks to the development of computers with increasing processing and memory capacities in association with the availability of more and more powerful, affordable digital imaging cameras. Combined with the surface marking technique, through anatomy palpation, the quantification and recording of postural asymmetries are possible using specific software. It is possible to use an image or sequence of images of the entire body for the purpose of qualitative or quantitative analysis. The computational techniques that make the gathering of $3 \mathrm{D}$ information from 2D images possible can be divided into two main categories: active and passive (Chen et al 2013). Active techniques can be described as those that involve the controlled projection of energy, such as light or ultrasound, onto the object or scene of interest. The reflected energy is then detected by sensors that directly or indirectly provide the desired 3D information. Examples of active techniques are active stereoscopy, Moiré, and echo-detection. Passive techniques do not involve the projection of any type of energy and work under ambient lighting. Passive techniques that may be cited are the ones based on passive stereoscopy and monocular images of intensity (Coelho \& Tavares 2003).

Beyond doubt, these new computer methods represented a great advance in comparison with the non-invasive solutions previously available. Nevertheless, even given the great effort put forth in the improvement of these technologies and methods, the true role of the measures obtained in the clinical setting is still undefined due to a number of remaining questions. For example, according to Don et al (2012), the main question is with respect to the definition of the parameters that significantly contribute to clinical decision-making. One of the challenges is the lack of databases containing postural data 
for healthy individuals that can be used in comparative studies. Mrozkowiak et al (2014) made the following considerations: (a) the assessment exam should be useful both for surgery and for preventive or follow-up cases; (b) the data acquisition and processing should be sufficiently fast in order for the results to be achieved during a typical clinical appointment; (c) the results achieved should be presented in a legible way, not only for the health professional, but also for the patient, and should be compared to patterns of well-known cases, preferably based on graphics and images; (d) the exam procedure should be sufficiently simple and as automated as possible, so it can be performed by health professionals; (e) the exam should be trustworthy, robust to operating errors, and not require the constant intervention of a specialist.

The objectives of the present study were: (a) to identify which postural evaluation methods, based on computer vision, have been proposed in the last five years; (b) to identify whether there is a proposal for whole body postural evaluation based on noninvasive methods for the diagnosis of AIS.

\section{METHODS}

A broad study of the literature was performed in the search for articles on static postural evaluation, particularly suitable for AIS, from 2D images based on computational methods. The databases searched were Scopus and Web of Science, as well as the biomedical databases of MEDLINE, ScieLo and PubMed. The search was restricted to the period between 2011 and 2015 and to articles published in English. In a second step, a complementary search was performed based on the reference list of the articles previously found. The inclusion criteria used were: non-invasive global postural evaluation, use of computational methods, and methods applicable to spine deformities, 
especially for AIS. The exclusion criteria included articles that approached treatments, methods that are not computer-based, and reviews.

Keywords

The following keywords were used in the initial search: postural evaluation, noninvasive monitoring, global body postural evaluation, computer vision and scoliosis evaluation, imaging and scoliosis diagnosis, postural and evaluation, and methods and scoliosis.

The complete texts of the selected articles were then subjected to critical analysis. Additionally, the QUADAS (Quality Assessment of Diagnostic Accuracy Studies) scale (Whiting et al 2013) was used as an evaluation tool for the quality of the studies selected. In this scale, which consists of a questionnaire of fourteen questions, the responses "yes", "no", or "unclear" are given. It is the responsibility of the researcher to evaluate the question of relevancy for the test. The QUADAS scale does not determine the minimum classification score, which should be decided by the researcher. In this study, the following scale was adopted for the classification of the articles found in terms of scientific evidence: 1) articles with up to 5 positives for the search criteria were classified as "low" evidence, 2) articles between 6 and 8 positives were classified as "moderate" evidence, and 3) articles above 8 positives were classified as "high" evidence.

\section{RESULTS}

One hundred and thirty-one articles were considered in the search done based on the keywords. Further, an additional three articles were found based on the references of the previously found articles. After removing the duplicate articles, eighty-three studies were considered for analysis. Twenty-five articles were excluded for treating pathological causes of scoliosis and associated pathologies. Forty-three articles were removed for not 
presenting non-invasive methods or for being review articles. Then, after the analysis of the abstracts, only fifteen articles that met the eligibility criteria were found. The flow diagram of the strategy adopted in the selection of the articles to be reviewed is presented in Figure 1.

$<$ Insert Figure 1 about here $>$

The articles selected for review, including the technology used, the objectives, and a summary of the methodology and results, are listed in Table 1.

$<$ Insert Table 1 about here $>$

The fifteen articles selected employed computer techniques for postural evaluation. Only two studies used a methodology involving contact with the patient, which was the acquisition of the 3D data using ultrasound systems (Kowalski et al 2014, Cheung et al 2015). The remaining studies used non-contact methods. Of these, four were based on passive 2D photogrammetry (Aroeira et al 2011, Saad et al 2012, Fortin et al 2012, Fortin et al 2013), while nine used active techniques: four articles were based on laser technology (Komeili et al 2015, Komeili et al 2014, Parent et al 2014, Rankine et al 2012), three on structured light (Glinkowski et al 2012, Weiss \& Seibel 2013, Glinkowski et al 2014) and, finally, two studies on Moiré projection (Sarnadskiy 2012a, 2012b), (see Figure 2).

Seven studies described non-invasive ways of measuring spine and posture asymmetries, and the methodological procedures for testing the reliability and validity of the 
instruments used (Cheung et al 2015, Komeili et al 2014, Kowalski et al 2014, Saad et al 2012, Fortin et al 2012, Rankine et al 2012, Weiss \& Seibel 2013). One study assessed the time effectiveness of the procedure employed (Weiss \& Seibel 2013), and the other six showed the use of non-invasive technologies to attain quantitative and/or qualitative information about trunk asymmetry (Komeili et al 2015, Parent et al 2014, Fortin et al 2013, Sarnadskiy 2012a, 2012b, Aroeira et al 2011).

$<$ Insert Figure 2 about here $>$

Quality assessment of the studies

Table 2 presents the results of the quality assessment of the studies found according to the QUADAS scale. The following answers were used as criteria evaluation: (y) yes; (n) no; (?) unclear; (-) not applicable (Whiting et al 2003).

According to the questions of the QUADAS tool, of the fifteen studies found, two presented low methodological quality, six presented moderate methodological quality, and seven studies presented high methodological quality.

$<$ Insert Table 2 about here $>$

\section{$\underline{\text { DISCUSSION }}$}

A review of the methods for non-invasive postural assessment of AIS based on computer techniques was accomplished. Some previous systematic review studies were 
found (Brink et al 2011, Fortin et al 2011, Don et al 2012, Mrozkowiak et al 2014, Prowse et al 2015), which analyzed several potential evaluation methods, including manual, visual, and computer based methods. According to the authors, despite many years of research, few tools are used in daily clinical practice, and a greater joint effort should be made by the clinical and biomechanical researchers to advance this field. No review study had methods based on techniques of computer vision for the evaluation of AIS as the focus.

In the studies analyzed, the use of several evaluation tools and diverse methodologies and protocols were observed. In some cases, despite the use of the same technology, different measurement protocols were presented, such as the cases based on laser technology (Komeili et al 2014, Parent et al 2014) and on 2D photogrammetry (Aroeira et al 2011, Fortin et al 2012, Saad et al 2012), making it difficult to perform a comparative analysis of these techniques. In many cases, the objectivity of the "gold standard", which is based on X-ray examinations was lacking. It is possible that this has contributed to the fact that no other method has yet to be universally accepted in clinical routines (Krejci et al 2012). Studies that employed surface topography based on active techniques, such as structured light, laser, and fringe projection, have shown to be of moderate to high quality. These techniques permit the evaluation of a large number of individuals, as the exam time is reduced, making them ideal for tracking postural alterations in school-age individuals, for example. However, these studies only presented protocols for the evaluation of the frontal back, omitting the possibility for an entire body evaluation. In addition, the high cost of the systems, and complexity in data interpretation may constitute a difficulty for their daily clinical use. The active techniques based on a 3D ultrasound system allow the assessment of the frontal and sagittal alignments of the spine, portability, and easy 
interpretation of results. However, it cannot be used to assess asymmetries in other anatomical regions of interest that are critical in the evaluation of AIS. The studies based on $2 \mathrm{D}$ photogrammetry for the postural evaluation, presented quantitative results that are easy to interpret, have a good level of reproducibility, and reliability. Of the four studies identified, only one presented an evaluation protocol beyond the region of the torso, including the analysis of the pelvis and lower limbs. The other three studies were limited to assessing asymmetries of the torso and spine. Despite it allowing a qualitative and quantitative assessment of the entire posture, portability, low cost, and objective results, the lack of automation in the measurement of each anatomic reference may consume excessive time in the examinations and require trained personnel. However, despite its limitations, the authors believe that noninvasive evaluation technology using 2D photogrammetry introduced itself as the best for assessing the complexity of postural changes observed in the AIS. This technology has enabled playback and quantification of the scoliotic curve, with direct comparison of the Cobb angle (Aroeira et al 2011), also allows a view of the whole body posture with kinematic measurements of body asymmetries (Fortin et al 2012). Its reproducibility can allow monitoring of postural changes over time using digital storage (Fortin et al 2012), which can feature as an important control tool in the evolution of the curve and the effectiveness of treatments in AIS. As the technique enables evaluations in different body plans, its $2 \mathrm{D}$ feature can be alleviated, allowing analysis of inferences in the 3D domain.

The non-invasive computer technologies identified in this study, were developed with the objective to become alternative methods to the X-ray exam. Current treatment paradigms for AIS are guided by torso evaluation and based largely on surgery. Wide variations exist in the decision making surrounding the treatment of scoliosis (Wang et al 
2014). It is commonly accepted that the evaluation of a deformity that presents the complexity of scoliosis, and has the potential to alter posture patterns of the individuals from the head to the feet, should not neglect its global body implications. Hence, evaluations solely related to the torso may offer incomplete information for suitable therapeutic interventions. Error! Reference source not found.depicts the radiological exams, with the respective Cobb angles, and pictures of two adolescents with similar patterns of scoliosis: thoracic curve convex to the right, apical vertebra T9 (A) and T8 (B), thoracic Cobb angle of $54.43^{\circ}$ and $51.30^{\circ}$, respectively (Aroeira et al 2011). Nevertheless, the two adolescents present distinct asymmetries in relation to the scapular belt, pelvic belt, head, and limbs.

$>$ insert Figure 3 about here $<$

Figure 4 shows a radiological image, a 13 year old adolescent, showing a small thoracic scoliosis (below $20^{\circ}$ ), which did not qualify for treatment under radiological parameters. However, in the posterior frontal photographic image of the same teen, significant postural asymmetries are shown throughout the body.

$>$ insert Figure 4 about here $<$

Some studies concluded that non-invasive methods still do not present sufficient trustworthiness in order to substitute the traditional X-ray exam for the evaluation of AIS (Saad et al 2012, Weiss \& Seibel 2013). However, attention should be given, also, on the distinct objectives of the pathological diagnosis versus the functional diagnosis using $\mathrm{X}$ - 
ray and non-invasive surface topography exams, respectively. This fact indicates the importance of the functional diagnosis and search for non-invasive exams, as these may significantly reduce the need for radiological exams in the monitoring of AIS, and will bring useful complementary information for the design of efficient therapeutic interventions in the future. Thus, the term "complement" appears to be more adequate than "substitute", for non-invasive methods of the postural evaluation of AIS.

Recent technological advances point to depth cameras, which permit the acquisition of dense 3D data of a scene in real time without the necessity of various imaging cameras and are low cost (Chen et al 2013, Akimoto et al 2013, Schwarz et al 2012, Clark et al 2012, Bonnechère et al 2014, Straub et al 2015). The use of these 3D sensors provides new opportunities for the acquisition of anthropometric data in a wide range of applications. However, the existing studies using these sensors have only focused on the qualitative estimation of the positioning of the human body, quantitative analysis related to the human torso, and knowledge of human actions.

\section{Limitations}

Given the complexity of the assessment of human posture and the variety of methodologies and technologies, there is no method to assess the quality of current studies that is universal and prevents erroneous results. For example, many items of the questionnaire used in the analysis presented in this study were not applicable to the study of Rankine et al (2012).

\section{$\underline{\text { CONCLUSION }}$}

An analysis of fifteen articles published in the period ranging from 2011 to 2015 
related to the non-invasive posture evaluation of AIS based on techniques of computer vision have been presented here. The findings revealed: (a). many alternative noninvasive techniques based on computer vision with different methodologies for the assessment of postural asymmetries, such as a topographic scanner with laser, measurements by 2D photogrammetry surface topography, a topographic scanner with structured light, a computational optical topography method with fringe projection, and an ultrasound scanner; (b) fourteen of the fifteen researched methodologies limited their assessment to the contour of the spine or the topography of the posterior back. Only one study, using the 2D photogrammetry technique, presented a possibility of whole body postural evaluation. AIS is a highly complex spinal deformity, characterized by the presence of significant asymmetries in the structure of the trunk, which may extend to the entire body. Thus, the whole body postural evaluation in individuals with AIS is of high interest for the improvement of functional diagnosis and the achievement of more efficient therapeutic interventions for the scoliosis cases diagnosed as "light" and "moderate". Hence, further studies are necessary to meet the complex challenge of finding a non-invasive human postural assessment method suitable for clinical use.

\section{Acknowledgements}

The authors thank to the Research Funding Agencies CAPES (Coordination of Improvement of Higher Education Personnel), CNPq (National Council of Scientific and Technological Development), and Minas Gerais State Research Foundation (FAPEMIG) for their financial supports, under Grant Numbers: 304275/2013-1, 44157-2 and TECPPM-00026-13. 


\section{$\underline{\text { REFERENCES }}$}

Akimoto T, Terada N, Yonezawa I, Muto O, Kawasaki T, Momomura R, Kaneko K, 2013. Development of Measurement System for Scoliosis Using 3D Camera. IEEJ Transactions on Electronics, Information and Systems, 133(11):2082-8.

Aroeira RMC, Leal JS, Pertence AEM, 2011. New Method of Scoliosis Assessment: Preliminary Results Using Computerized Photogrammetry. Spine, 36:1584-91.

Berrington de Gonzales A, Darby S, 2004. Risk of cancer from diagnostic X-rays: estimates for the UK and 14 other countries. Lancet, 363:345-51.

Bettany-Saltikov J, Cook T, Rigo M, De Mauroy JC, Romano M, Negrini S, Durmala J et al. Physical Therapy for Adolescent with Idiopathic Scoliosis. In: InTech, editors. Physical Therapy Perspectives in the $21^{\text {st }}$ Century, Rijeka, Croatia; 2012, p.1.

Bone CM, Hsieh GH, 2000. The risk of carcinogenesis from radiographs to pediatric orthopedic patients. Journal Pediatrics Orthopedics, 20:251-54.

Bonnechère B, Jansen B, Salvia P, Bouzahouene H, Omelina L, Moiseev F, et al., 2014. Validity and reability of the Kinect within functional assessment activities: comparison with standard stereophotogrammetry. Gait \& Posture, 39:593-98.

Brink Y, Louw Q, Somers KG, 2011. The quality of evidence of psychometric properties of three-dimensional spinal posture-measuring instruments. BMC Musculoskelet D, 
$12: 93$.

Chen L, Wei H, Ferryman J, 2013. A survey of human motion analysis using depth imagery. Patter Recognition Letters, 34:1995-2006.

Cheung CWJ, Zhou GQ, Law SY, Mak TM, Lai KL, Zheng YP, 2015. Ultrasound Volume Projection Imaging for Assessment of Scoliosis. IEEE Trans Med Imaging, 34(8):17608.

Clark RA, Pua YH, Fortin K, Ritchie C, Webster KE, Donehy L, Bryant AL, 2012. Validity of the Microsoft Kinect for assessment of postural control. Gait \& Posture, $36: 372-77$.

Coelho CP, Tavares JM, 2003. Técnicas base para aquisição de informação tridimensional sem contacto. Revista Eletrônica de Sistemas de Informação, 2:1-11 (in Portuguese).

Don R, Capodaglio P, Cimolin V, Benedetti MG, D'Osualdo F, Frigo C, Vismara L, Negrini S, 2012. Instrumental measures of spinal function: is it worth? A state-of-the art from a clinical perspective. European Journal of Physical Rehabilitation Medical, 48: 255-73.

Doody M, Lonstein JE, Stovall M, Hacke DG, Luckyanov N, Land CE, 2000. Breast cancer mortality after diagnostic radiography: finding from the U.S. Scoliosis Cohort Study. Spine, 25:2052-63. 
Driscoll M, Aubin CE, Moreau A, Villemure I, Parent E, 2009. The role of spinal concaveconvex biases in the progression of idiopathic scoliosis. Euro Spine Journal, 18:180-87.

Enríquez G, Piqueras J, Catalá A, Oliva G, Ruiz A, Ribas M, et al., 2014. Optimization of radiological scoliosis assessment. Medical Clinics, 143:62-7.

Filipovic V, Ciliga D, 2010. Postural Adaptation of Idiopathic Adolescent Scoliosis (IAS). Kinesiology, 42:16-27.

Fortin C, Feldman DE, Cheriet F, Labelle H, 2011. Clinical methods for quantifying body segment posture: a literature review. Disability and Rehabilitation, 33:367-83.

Fortin C, Feldman DE, Cheriet F, Gravel D, Gauthier F, Labelle H, 2012. Reliability of a quantitative clinical posture assessment tool among persons with idiopathic scoliosis. Physiotherapy, 98:64-75.

Fortin C, Feldman DE, Cheriet F, Labelle H, 2013. Differences in Standing and Sitting Postures of Youth with Idiopathic Scoliosis from Quantitative Analysis of Digital Photographs. Physical Therapy Pediatrics, 33:313-26.

Glinkowski W, Michonski J, Glinkowska B, Zukowska A, Sitnik R, Gorecki A, 2012. Telediagnostic 3D school screening of back curvatures and posture using structured light method - pilot study. Studies in Health Technology Information, 176:291-94. 
Glinkowski W, Michouski J, Zukowska A, Glinkowska B, Sitnik R, Gorecki A, 2014. The time Effectiveness of Three-Dimensional Telediagnostic Postural Screening of Back Curvature and Scoliosis. Telemedicine Journal E-Health, 20:11-7.

Goldberg MS, Mayo NE, Levy AR, Scott SC, Poitras B, 1998. Adverse reproductive outcomes among women exposed to low levels of ionizing radiation from diagnostic radiography for adolescent idiopathic scoliosis. Epidemiology, 9:271-78.

Han J, Xu Q, Yang Y, Yao Z, Zhang C, 2015. Evaluation of quality of life and risk factors affecting quality of life in adolescent idiopathic scoliosis. Intractable \& Rare Diseases Research, 4:12-16.

Komeili A, Westover LM, Parent EC, Moreau M, El-Rich M, Adeeb S, 2014. Surface topography asymmetry maps categorizing external deformity in scoliosis. Spine Journal, 14:973-83.

Komeili A, Westover L, Parent E, Adeeb S, 2015. Monitoring for Idiopathic Scoliosis Curve Progression Using Surface Topography Asymmetry Analysis of the Torso in Adolescents. Spine Journal, 15:743-51.

Kowalski IM, Protasiewicz-Faldowska H, Dwornik M, Pierozynski B, Raistenskis J, Kiebzak W, 2014. Objective parallel-forms reliability assessment of 3 dimension real time body posture screening tests. BMC Pediatric, 14:221. 
Krejci J, Gallo J, Stepanik P, Salinger J, 2012. Optimization of the examination posture in spinal curvature assessment. Scoliosis, 7:10.

Levy AR, Goldberg MS, Hanley JA, Mayo NE, Poitras B, 1994. Projecting the lifetime risk of cancer from exposure to diagnostic ionizing radiation for adolescent idiopathic scoliosis. Health Physics, 66:621-33.

Magee DJ. Assessment of Posture. In: DJ Magee (Ed), Orthopedic physical assessment. Saunders Company: New York, 1992. p. 579-608.

Mrozkowiak M, Szark-Eckark M, Zukowska H, Zukow W, 2014. Review of Methods for Assessing Body Posture. Journal Health Science, 4:95-102.

Ovadia D, Bar-On E, Fragniere B, Rigo M, Dickman D, Leitner J, Wientroub S, Dubousset J, 2007. Assessment of scoliosis: A multi center prospective study. European Spine Journal, 16:97-105.

Panagiotopoulou O, 2009. Finite Element Analysis (FEA): Applying an Engineering Method to Functional Morphology in Anthropology and Human Biology. Annals Human Biology, 36:609-23.

Parent EC, Chabot S, Westover L, Hill D, Moreau M, Hedden D, Lou E, Adeeb S, 2014. The Ability of Surface Topography Postural Measurements to Detect Cobb Angle 
Progression in Adolescents with Idiopathic Scoliosis (AIS) and a Main Thoracic Curve: Full Torso Scans Compared to Back Only Parameters. Scoliosis, 9(1):010.

Prowse A, Pope R, Gerdhem P, Abbott A, 2015. Reliability an validity of inexpensive and easily administered anthropometric clinical evaluation methods of postural asymmetry measurement in adolescent idiopathic scoliosis: a systematic review. European Spine Journal (in press).

Rankine L, Liu XC, Tassone C, Lyon R, Tarima S, Thometz J, 2012. Reproducibility of Newly Developed Spinal Topography Measurements for Scoliosis. The Open Orthopedics Journal, 6:226-30.

Ricieri DV, Filho NAR, 2009. Effectiveness of a photogrammetric model for the analysis of thoracoabdominal respiratory mechanics in the assessment of isovolume maneuvers in children. Journal Brazilian Pneumology, 35:145-52.

Ron E, 2003. Cancer risks from medical radiation. Health Physics, 85:47-59.

Rosário JLP, 2014. Photographic Analysis of Human Posture: A literature Review. Journal of Bodywork and Movement Therapies, 18:56-61.

Saad KR, Colombo AS, Ribeiro AP, João SMA, 2012. Reliability of photogrammetry in the evaluation of the postural aspects of individuals with structural scoliosis. Journal of Bodywork \& Movement Therapies, 16:210-16. 
Saccucci M, Tettamanti L, Mummolo S, Polimeni A, Festa F, Salini V, Tecco S, 2011. Scoliosis and dental occlusion: a review of the literature. Scoliosis Journal, 6:15.

Sarnadskiy VN, 2012(a). The structure of postural disorders and spinal deformities in age and gender according to computer optical topography. Studies in Health Technology Information, 176:77-82.

Sarnadskiy VN, 2012(b). Classification of postural disorders and spinal deformities in the three-dimensions according to computer optical topography. Studies in Health Technology Information, 176:159-163.

Schwarz LA, Mkhitaryan A, Mateus D, Navab N, 2012. Human skeleton tracking from depth data using geodesic distances and optical flow. Image Vision Computer, 30:217-26.

Singla D, Vegar Z, 2014. Methods of postural Assessment used for sports persons. J Clinical Diagnostic Research, 8:LE01- LE04.

Singla D, Veqar Z, 2015. Effect of playing basketball on the posture of cervical spine in healthy collegiate students. International Journal of Biomedical and Advance Research, 6:133-36.

Smidt GL, Day JW, Gerleman DG,1984. Lowa anatomical position system. A method of assessing posture. European Journal of Applied Physiology and Occupational Physics, 52:407-13. 
Stemper BD, Board D, Yoganandan NY, Wolfla CE, 2010. Biomechanical Properties of Human Thoracic Spine Disc Segments. Journal of Craniovertebral Junction \& Spine, $1: 18-22$

Straub J, Kading B, Mohammad A, Kerlin S, 2015. Characterization of a large, low-cost 3D scanner. Technologies, 3:19-36.

Subasi F. Posture, Kinesis and Proprioception In: Proprioception: The Forgotten Sixth Sense. Foster City, CA: Defne Kaya; 2014.

Tavares, João Manuel R. da Silva. Obtenção de Estrutura Tridimensional a partir de Movimento de Câmara. 1995. MSc Thesis - Faculdade de Engenharia da Universidade do Porto, Portugal (in Portuguese).

Van der Plaats A, Veldhuizen AG, Verkerke GJ, 2007. Numerical Simulation of Asymmetrically Altered Growth as Initiation Mechanism of Scoliosis. Annals Biomedical Engineering, 35:1206-15.

Wang W, Baran GR, Betz RR, Samdani AF, Pahys JM, Cahill PJ, 2014. The use of Finite Element Models to Assist Understanding and treatment for Scoliosis: A Review Paper. Spine Deformity, 2:10-27.

Weiss HR, Seibel S, 2013. Can surface topography replace radiography in the 
management of patients with scoliosis? Hard Tissue, 2:19.

Whiting P, Rutjes A W S, Reitsma J B, Bossuyt P M M, Kleijnen J, 2003. The development of QUADAS: A tool for the quality assessment of studies of diagnostic accuracy included in systematic reviews. BMC Medical Research Methodology, 3:25.

Zsidai A, Kocsis L, 2003. Ultrasound-based spinal column examination systems. Fact Physical Education and Sport, 1:1-12. 


\section{TABLE CAPTIONS}

Table 1. Summary of the fifteen studies included in the systematic review.

Table 2. Summary of the quality assessment of the studies found $(n=15)$ (adapted from Brink et al 2011). 


\section{FIGURE CAPTIONS}

Figure 1. Flow diagram of the articles selection process.

Figure 2. Diagram of the methods used in the studies found regarding non-invasive postural evaluation.

Figures 3. (a) Measurement of the thoracic Cobb angle in X-ray images of two adolescents: Adolescent A - apical vertebra T9 $\left(54.43^{\circ}\right)$, and Adolescent B - apical vertebra T8 $\left(51.20^{\circ}\right)$; (b) Frontal posterior images of the adolescents A and B that present similar scoliosis curvature: double curve, principally thoracic with convex curvature to the right, thoracic angle between $50^{\circ}$ and $55^{\circ}$, apical vertebral $\mathrm{T} 9$ and $\mathrm{T} 8$, and presenting distinct body asymmetries (Aroeira et al 2011)

Figure 4. (a) a radiological image, a 13 year old adolescent, showing a small thoracic scoliosis (below 20 ); (b) a posterior frontal photographic image of the same teen, showing significant postural asymmetries throughout the body (Aroeira et al 2011) 


\section{FIGURES}

Figure 1

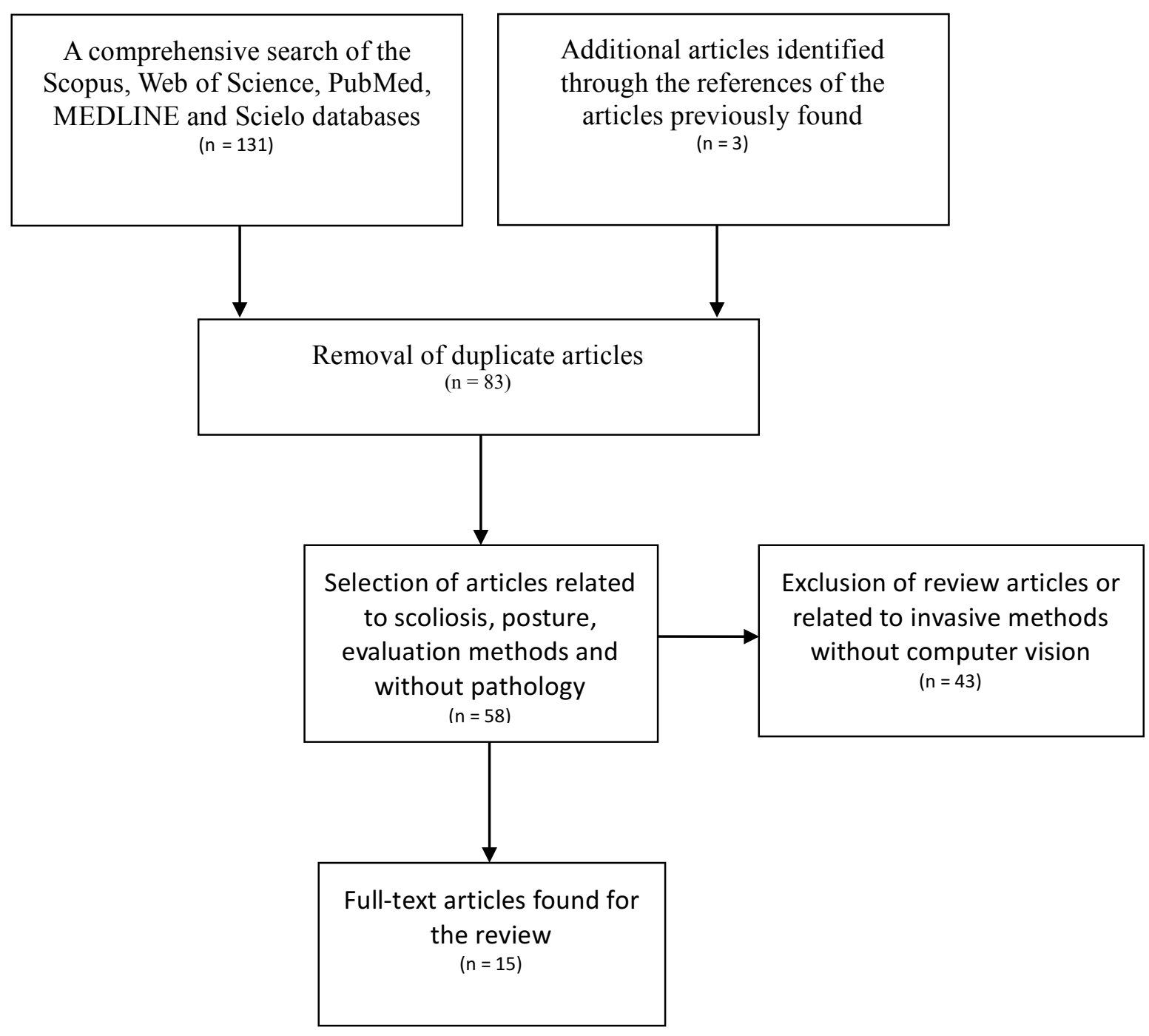


Figure 2

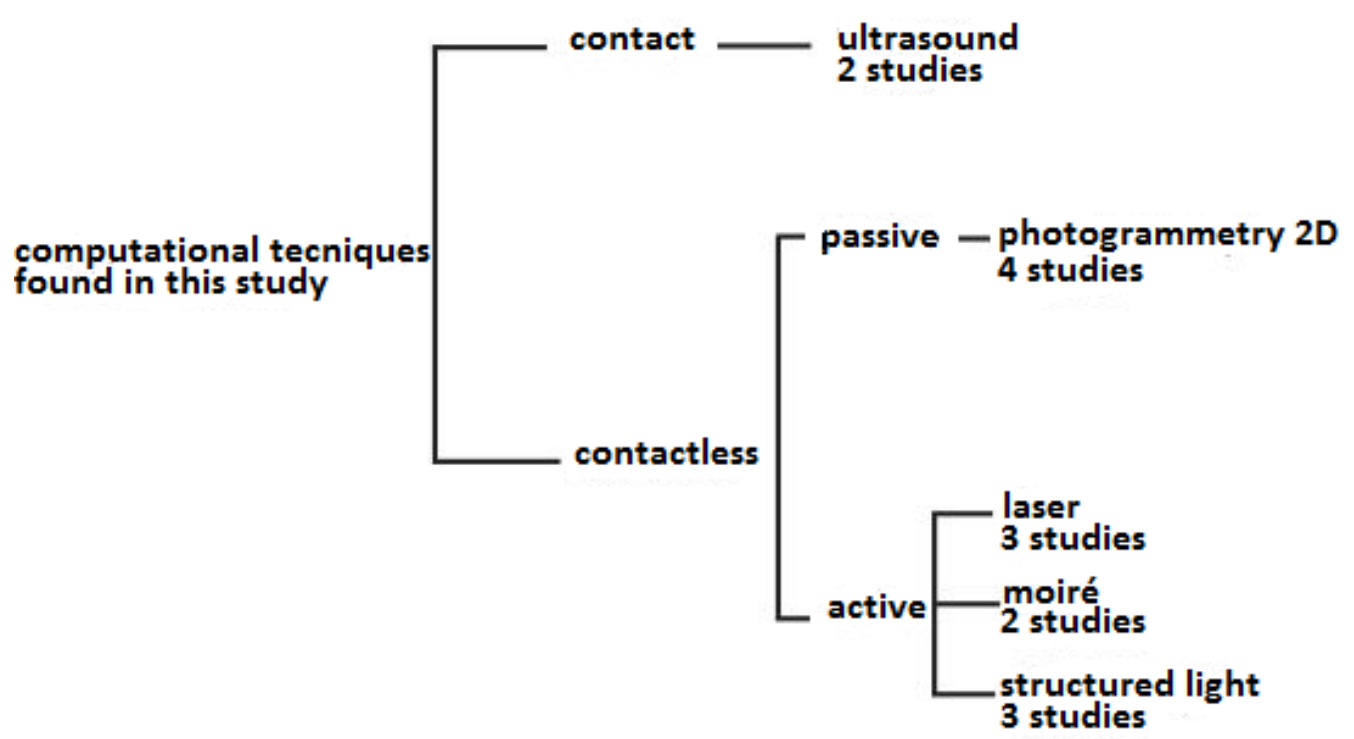


Figure 3

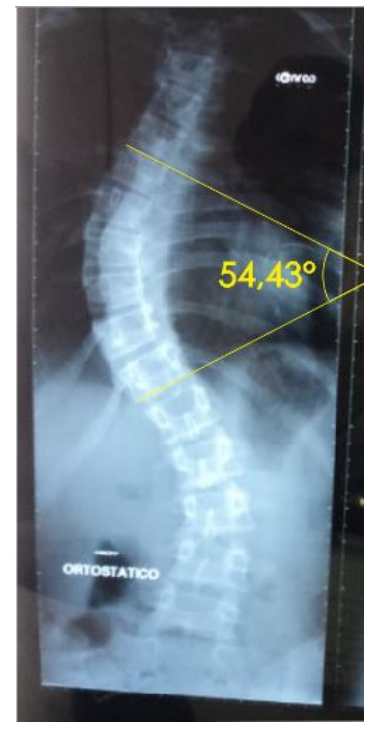

A

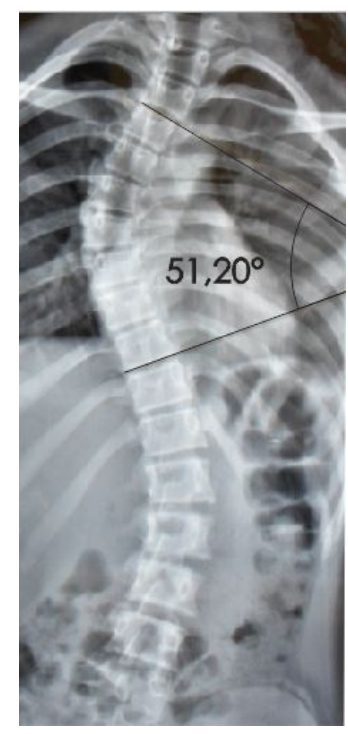

B

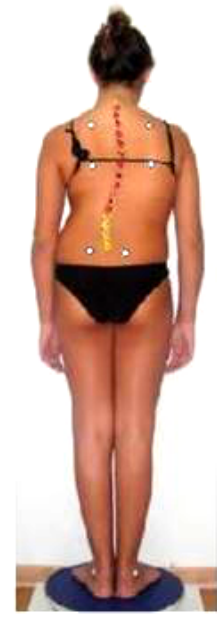

A

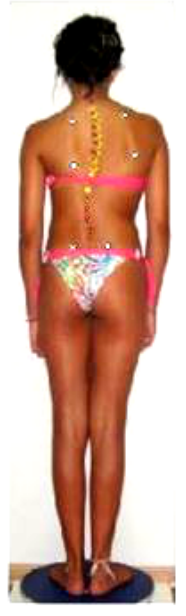

B

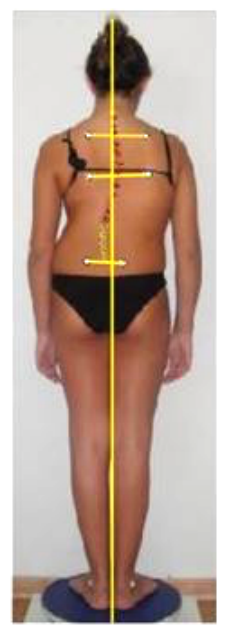

A

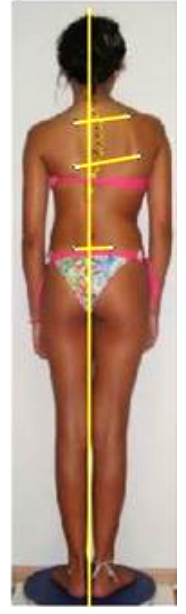

B

(a)

(b) 
Figure 4

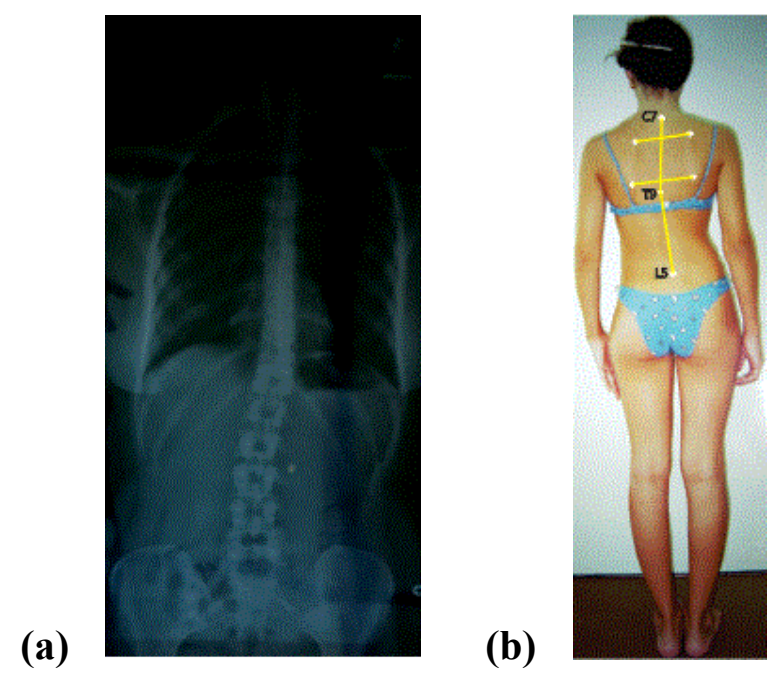




\section{TABLES}

\section{Table 1}

\begin{tabular}{|c|c|c|c|}
\hline STUDY & SYSTEM & OBJECTIVE and METHODS & RESULTS \\
\hline $\begin{array}{l}\text { Aroeira et al. } \\
\text { (2011) }\end{array}$ & $\begin{array}{l}\text { 2D } \\
\text { Photogrammetry, } \\
\text { natural light }\end{array}$ & $\begin{array}{l}\text { To develop a protocol for computerized } \\
\text { photogrammetry, as a nonradiographic method, } \\
\text { for the quantification of scoliosis. } \\
\text { Sixteen AIS patients, } 21.4 \pm 6.1 \text { years of age, } \\
\text { undergoing standing poster anterior full-length } \\
\text { spine radiographs, were submitted to dorsal } \\
\text { digital photography in the orthostatic position } \\
\text { with special surface makers over the spinous } \\
\text { process C7-L5. }\end{array}$ & $\begin{array}{l}\text { The results demonstrate } \\
\text { equivalence between the two } \\
\text { methods. There was no } \\
\text { statistically significant difference } \\
\text { between the scoliosis angle } \\
\text { measurements obtained in the } \\
\text { comparative analysis of both } \\
\text { methods. }\end{array}$ \\
\hline $\begin{array}{l}\text { Rankine et } \\
\text { al. (2012) }\end{array}$ & $\begin{array}{l}\text { Milwaukee } \\
\text { Topographic } \\
\text { Scanner/MTS Laser }\end{array}$ & $\begin{array}{l}\text { In an effort to limit exposure to ionizing radiation } \\
\text { and fully characterize three-dimensional changes } \\
\text { in the spine of patients with scoliosis reliable non- } \\
\text { invasive methods of spinal back contour analysis } \\
\text { was made. } \\
\text { A dummy cast (plastic cast) of one patient with AIS } \\
\text { was built in order to test the reliability of the MTS. }\end{array}$ & $\begin{array}{l}\text { All measurements of intra-rater } \\
\text { and inter-rater reliability were } \\
\text { excellent (ICC ranging from } 0.89 \\
\text { to } 0.99 \text { ) with the exception of } \\
\text { pelvic tilt (ICC } 0.61 \text { ) and lordosis } \\
\text { angle (ICC } 0.82 \text { ). No significant } \\
\text { variability among investigators } \\
\text { was observed for all tested } \\
\text { metrics. }\end{array}$ \\
\hline $\begin{array}{l}\text { Glinkowski } \\
\text { et al. (2012) }\end{array}$ & $\begin{array}{l}\text { 3D Orthoscreen } \\
\text { structured light }^{\mathrm{TM}}\end{array}$ & $\begin{array}{l}\text { To determine usefulness of school screening back } \\
\text { evaluation performed utilizing the three- } \\
\text { dimensional telediagnostic measurement system. } \\
\text { Were examined } 758 \text { children averagely aged } 11.1 \\
\text { years (from } 5 \text { to } 16 \text { ). The measurement module } \\
\text { is based on the structured light method. }\end{array}$ & $\begin{array}{l}\text { The average values of to back } \\
\text { assessment parameters were as } \\
\text { follows: axial plane (DAPI) was } \\
0.88 \% \text { and the symmetry } \\
\text { parameter of the back (POTSI) } \\
\text { was altered in } 15.97 \% \text {. Kyphosis } \\
\text { angle was equal to } 10.19^{\circ} \text { and } \\
\text { lordosis angle to } 32.82^{\circ} \text {. }\end{array}$ \\
\hline $\begin{array}{l}\text { Fortin et al. } \\
\text { (2012) }\end{array}$ & $\begin{array}{l}\text { 2D } \\
\text { Photogrammetry, } \\
\text { natural light }\end{array}$ & $\begin{array}{l}\text { To determine overall test-retest and inter-rater } \\
\text { reliability of posture indices among AIS persons. } \\
\text { Seventy subjects aged between } 10 \text { and } 20 \text { years with } \\
\text { AIS. Markers placed on several anatomical } \\
\text { landmarks, } 32 \text { angular and linear posture indices } \\
\text { taken from digital photographs in the standing were } \\
\text { calculated using a software. }\end{array}$ & $\begin{array}{l}\text { In the random design, the } \\
\text { dependability coefficients } \\
\text { demonstrated a moderate level } \\
\text { of reliability for } 6 \text { posture indices } \\
(\varnothing=0.51-0.72) \text { and a good level } \\
\text { of reliability for } 26 \text { posture } \\
\text { indices out of } 32(\varnothing \geq 0.79) \text {. }\end{array}$ \\
\hline
\end{tabular}


Table 1 - Cont.

\begin{tabular}{|c|c|c|c|}
\hline STUDY & SYSTEM & OBJECTIVE and METHODS & RESULTS \\
\hline $\begin{array}{l}\text { Saad et al. } \\
\text { (2012) }\end{array}$ & $\begin{array}{l}\text { 2D } \\
\text { Photogrammetry, } \\
\text { natural light }\end{array}$ & $\begin{array}{l}\text { To investigate the reliability of photogrammetry in } \\
\text { the measurement of the postural deviation in } \\
\text { individuals with AIS. } \\
\text { Twenty patients with AIS, with a mean of } 23.1 \pm 9 \\
\text { years age, were photographed from the posterior } \\
\text { and lateral views with surface markers. The } \\
\text { postural aspects were calculated using CorelDraw. }\end{array}$ & $\begin{array}{l}\text { High inter-rater and test-retest } \\
\text { reliability indices were found. It } \\
\text { was observed that as more severe } \\
\text { the scoliosis was, greater were the } \\
\text { variations between the thoracic } \\
\text { kyphosis and lumbar lordosis, } \\
\text { with the measures obtained by the } \\
\text { same investigator from the left } \\
\text { lateral view. }\end{array}$ \\
\hline $\begin{array}{l}\text { Sarnadskiy } \\
(2012)(a)\end{array}$ & $\begin{array}{ll}\text { Computer } & \text { Optical } \\
\text { Topography } & \\
\text { (TODP), fringe } \\
\text { projection }\end{array}$ & $\begin{array}{l}\text { To explore gender and age features of the postural } \\
\text { formation. } \\
\text { Were examined } 33000 \text { children and adolescents, } \\
\text { aged from } 5 \text { to } 17 \text { years, with a TODP system based } \\
\text { on a computational optical topography method. }\end{array}$ & $\begin{array}{l}\text { The most significant differences } \\
\text { in the postural formation between } \\
\text { boys and girls were identified in } \\
\text { the sagittal plane. A strong } \\
\text { correlation between the } \\
\text { development of structural } \\
\text { scoliosis and growth of the body } \\
\text { for both genders was found in the } \\
\text { frontal plane. }\end{array}$ \\
\hline $\begin{array}{l}\text { Sarnadskiy } \\
(2012)(b)\end{array}$ & $\begin{array}{l}\text { Computer } \\
\text { Topography } \\
\text { (TODP), } \\
\text { projection }\end{array}$ & $\begin{array}{l}\text { To create a new classification of the postural } \\
\text { disorder and spinal deformity varieties. } \\
\text { Based on a fringe projection method and phase } \\
\text { special detection, the classification is based on three- } \\
\text { dimensional estimation of the trunk and on the } \\
\text { orthopedic division of structural scoliosis. }\end{array}$ & $\begin{array}{l}\text { In the frontal plane, there were } 4 \\
\text { varieties: without scoliosis, } \\
\text { functional scoliosis, compensatory } \\
\text { scoliosis and structural scoliosis. In } \\
\text { sagittal plane, posture was divided } \\
\text { into } 3 \text { variants: balanced kyphosis } \\
\text { and lordosis, predominance of } \\
\text { lordosis and predominance of } \\
\text { kyphosis. In horizontal plane, } 3 \\
\text { variants were considered: rotated } \\
\text { pelvis, rotated shoulder girdle and } \\
\text { twisted trunk. }\end{array}$ \\
\hline
\end{tabular}


Table 1 - Cont.

\begin{tabular}{|c|c|c|c|}
\hline STUDY & SYSTEM & OBJECTIVE and METHODS & RESULTS \\
\hline $\begin{array}{l}\text { Fortin et al. } \\
\text { (2013) }\end{array}$ & $\begin{array}{l}\text { 2D } \\
\text { Photogrammetry, } \\
\text { natural light }\end{array}$ & $\begin{array}{l}\text { To explore whether differences in standing and } \\
\text { sitting postures of youth with AIS could be detected } \\
\text { from quantitative analysis of digital photographs. } \\
\text { Fifty participants aged } 10-20 \text { years old, with AIS, } \\
\text { were assessed from digital photographs using a } \\
\text { posture evaluation software program. Based on the } \\
\text { XY coordinates of markers, } 13 \text { angular and linear } \\
\text { posture were calculated. }\end{array}$ & $\begin{array}{l}\text { Significant differences between } \\
\text { standing and sitting positions } \\
(p<0.05) \text { were found for head } \\
\text { protraction, shoulder elevation, } \\
\text { scapula asymmetry, trunk list, } \\
\text { scoliosis angle, waist angles and } \\
\text { frontal and sagittal plane pelvic } \\
\text { tilt. }\end{array}$ \\
\hline $\begin{array}{l}\text { Weiss et al. } \\
\text { (2013) }\end{array}$ & $\begin{array}{l}\text { Formetric }{ }^{\circledR} \text { scan, } \\
\text { structured light }\end{array}$ & $\begin{array}{l}\text { To analyze patients to test the repeatability of the } \\
\text { results from that previously reported using the } \\
\text { Diers Formetric system. } \\
\text { Twenty-five patients with AIS had a Formetric }{ }^{\circledR} \\
\text { scan and anteroposterior X-ray of the spine at the } \\
\text { time they presented for having their first brace in } \\
\text { the office of an expert. The average age was } 12.9 \\
\text { years. The Cobb angle was correlated to the scoliosis } \\
\text { angle (AS) by the Formetric }{ }^{\circledR} \text { system. }\end{array}$ & $\begin{array}{l}\text { Correlation found was relatively } \\
\text { high }(r=0.84) \text { and differences } \\
\text { between the two series of } \\
\text { measurement were not significant } \\
(p=0.08) \text { However, only } 9 / 25 \\
\text { measurements were in the range of } \\
\text { the technical error }\left( \pm 5^{\circ}\right) \text {. In } 12 / 25 \\
\text { patients, the } \text { Formetric }{ }^{\circledR} \\
\text { measurements were six or more } \\
\text { degrees too low, and in } 4 / 25 \text {, were } \\
\text { six or more degrees too high. }\end{array}$ \\
\hline $\begin{array}{l}\text { Glinkowski } \\
\text { et al. (2014) }\end{array}$ & $\begin{array}{l}\text { 3D Orthoscreen }{ }^{\mathrm{TM}} \text {, } \\
\text { structured light }\end{array}$ & $\begin{array}{l}\text { To assess the time effectiveness of implemented } \\
\text { telediagnostic screening procedures. } \\
\text { Medical images (virtual objects) of acquired clouds } \\
\text { of points of } 100 \text { subjects. The study was performed } \\
\text { using a newly developed three-dimensional back } \\
\text { surface topography measurement system for } \\
\text { posture and scoliosis using a structured light } \\
\text { method. }\end{array}$ & $\begin{array}{l}\text { The overall assessment of all } \\
\text { subjects took from } 2 \mathrm{~h} 55 \mathrm{~min} 55 \mathrm{~s} \text { to } \\
3 \mathrm{~h} 18 \mathrm{~min} 59 \mathrm{~s} \text { dependent on } \mathrm{PC} \text { and } \\
\text { Internet connection configuration. } \\
\text { The average examination time per } \\
\text { subject ranged from } 2 \mathrm{~min} 43 \mathrm{~s} \text { to } \\
\text { 4min } 51 \mathrm{~s}\end{array}$ \\
\hline
\end{tabular}


Table 1 - Cont.

\begin{tabular}{|c|c|c|c|}
\hline STUDY & SYSTEM & OBJECTIVE and METHODS & RESULTS \\
\hline $\begin{array}{l}\text { Kowalski et } \\
\text { al. (2014) }\end{array}$ & $\begin{array}{lr}\text { Zebris } & \text { CMS-10 } \\
\text { system, ultrasound } \\
\text { scanner }\end{array}$ & $\begin{array}{l}\text { To assess the reliability of clinical evaluation of body } \\
\text { posture compared to objective assessment with the } \\
\text { Zebris CMS-10 system. } \\
\text { The study enrolled } 138 \text { participants, } 13-15 \text { years-old } \\
\text { pupils attending a junior secondary school, who } \\
\text { underwent a clinical evaluation of the body posture } \\
\text { and examination with the Zebris CMS-10 system. }\end{array}$ & $\begin{array}{l}\text { Statistically } \\
\text { discrepancies between the clinical } \\
\text { and objective evaluation were noted } \\
\text { with regard to lumbar lordosis in } \\
\text { boys }(n=67) \text { and thoracic kyphosis } \\
\text { in girls ( } n=71) \text {. No statistically } \\
\text { significant differences in both } \\
\text { groups were found for pelvic } \\
\text { rotation and trunk position in the } \\
\text { frontal plane. }\end{array}$ \\
\hline $\begin{array}{l}\text { Komeili et al. } \\
\text { (2014) }\end{array}$ & $\begin{array}{l}4 \quad \text { Minolta laser } \\
\text { scanners, 3D Laser }\end{array}$ & $\begin{array}{l}\text { This study introduced a three-dimensional marker- } \\
\text { less analysis technique for assessing torso } \\
\text { asymmetry in AIS and a system for classifying } \\
\text { patients based on this technique. } \\
\text { Full-torso ST scans of } 46 \text { patients with AIS and five } \\
\text { healthy subjects were used for analysis. A second } \\
\text { baseline scan and a } 1 \text {-year follow-up scan were } \\
\text { analyzed for } 15 \text { subjects. }\end{array}$ & $\begin{array}{l}\text { Distinct patterns of asymmetry } \\
\text { were identified allowing patients to } \\
\text { be classified into three groups, with } \\
\text { six subgroups based on their } \\
\text { asymmetry map with very good to } \\
\text { excellent reliability. }\end{array}$ \\
\hline $\begin{array}{l}\text { Parent et al. } \\
\text { (2014) }\end{array}$ & $\begin{array}{l}4 \text { Minolta laser } 910 \\
\text { scanners }\end{array}$ & $\begin{array}{l}\text { To compare the ability of full-torso and back-only } \\
\text { ST parameters to detect which curves do not } \\
\text { progress by }>5^{\circ} \text { in AIS a main thoracic curve. } \\
\text { Full-torso ST scans and frontal back (only) ST of } 42 \\
\text { adolescents, age } 13.9 \pm 1.7 \text { years, Cobb angle } 24 \pm 12^{\circ} \\
\text { at baseline and } 25 \pm 16^{\circ} \text { at } 1 \text { year. One evaluator } \\
\text { marked } 11 \text { reference points that were scanned. Data } \\
\text { analysis performed in Matlab by digitizing the } \\
\text { landmarks on images presented in random order } \\
\text { blind to timing of the scan. } 30 \text { Full-torso and } 16 \\
\text { back-only parameters were used. }\end{array}$ & $\begin{array}{l}\text { The area under the receiver } \\
\text { operator characteristic curves } \\
\text { (AUC) was used to compare the } \\
\text { accuracy in determining which } \\
\text { curves did not progress. } \\
\text { The absolute change in only } 2 \text { full- } \\
\text { torso ST parameters had } \\
\text { statistically significant ability to } \\
\text { predict which curve remained } \\
\text { stable. } \\
\text { Back-only parameters did not have } \\
\text { significant AUC. }\end{array}$ \\
\hline
\end{tabular}


Table 1 - Cont.

\begin{tabular}{|c|c|c|c|}
\hline STUDY & SYSTEM & OBJECTIVE and METHODS & RESULTS \\
\hline $\begin{array}{l}\text { Komeili et al. } \\
\text { (2015) }\end{array}$ & $\begin{array}{l}4 \quad \text { Minolta laser } \\
\text { scanners, 3D Laser }\end{array}$ & $\begin{array}{l}\text { To determine the capability of the } 3 \mathrm{D} \text { markerless ST } \\
\text { asymmetry analysis to detect } \geq 5^{\circ} \text { progression in the } \\
\text { spinal curvature in patients with AIS over one year } \\
\text { follow-up interval. } \\
\text { In this study, baseline and one year follow-up full } \\
\text { torso ST scans of } 100 \text { patients with AIS were } \\
\text { analyzed using 3D markerless asymmetry analysis. }\end{array}$ & $\begin{array}{l}\text { The classification model detected } \\
85.7 \% \text { of the progression and } 71.6 \% \\
\text { of the non-progression cases. The } \\
\text { resulting false negative rate of } 4 \% \\
\text { for T-TL curves, representing the } \\
\text { proportion of undetected } \\
\text { progressions, confirmed that the } \\
\text { technique shows promise to monitor } \\
\text { the progression of T-TL scoliosis } \\
\text { curves. }\end{array}$ \\
\hline $\begin{array}{l}\text { Cheung et } \\
\text { al. (2015) }\end{array}$ & $\begin{array}{l}\text { Freehand 3-D } \\
\text { Ultrasound system }\end{array}$ & $\begin{array}{l}\text { A reliability study, } 36 \text { subjects (age } 30.1 \pm 14.5 ; 12 \\
\text { male and } 24 \text { female) with different degrees of } \\
\text { scoliosis were scanned using the system and } \\
\text { submitted to poster anterior full-length spine } \\
\text { radiographs to test the inter- and intra-observer } \\
\text { repeatability. }\end{array}$ & $\begin{array}{l}\text { The inter- and intra-observer tests } \\
\text { indicated that the new assessment } \\
\text { methods were repeatable, with ICC } \\
\text { larger than } 0.92 \text {. Small intra- and } \\
\text { inter-observer variations of } \\
\text { measuring spine curve were } \\
\text { observed for the two methods. The } \\
\text { results also showed good linear } \\
\text { correlations with X-ray Cobb's } \\
\text { method (R2=0.8, p<0.001, } 29 \\
\text { subjects). }\end{array}$ \\
\hline
\end{tabular}


Table 2

\begin{tabular}{|c|c|c|c|c|c|c|c|c|c|c|c|c|c|c|c|c|}
\hline \multirow{3}{*}{$\begin{array}{l}\text { STUDY } \\
\text { Cheung et al.(2015) }\end{array}$} & \multicolumn{15}{|c|}{ CRITERIAQUADAS SCALE } & \multirow[b]{2}{*}{ CLASSE } \\
\hline & 1 & 2 & 3 & 4 & 5 & 6 & 7 & 8 & 9 & 10 & 11 & 12 & 13 & 14 & TOTAL & \\
\hline & $\mathrm{y}$ & $\mathrm{y}$ & $\mathrm{y}$ & $?$ & $\mathrm{y}$ & $\mathrm{y}$ & $\mathrm{y}$ & $\mathrm{y}$ & $\mathrm{y}$ & $?$ & $\mathrm{y}$ & $\mathrm{y}$ & - & - & 10 & $\mathrm{HIGH}$ \\
\hline Komeili et al.(2015) & $\mathrm{y}$ & $\mathrm{y}$ & $\mathrm{y}$ & $\mathrm{y}$ & $\mathrm{y}$ & $\mathrm{y}$ & $\mathrm{y}$ & $\mathrm{y}$ & $\mathrm{y}$ & $?$ & $?$ & $\mathrm{y}$ & - & $\mathrm{y}$ & 11 & $\mathrm{HIGH}$ \\
\hline Kowalski et al. (2014) & $\mathrm{y}$ & $\mathrm{y}$ & $\mathrm{y}$ & $\mathrm{y}$ & $\mathrm{y}$ & $\mathrm{y}$ & $\mathrm{y}$ & $?$ & $?$ & $\mathrm{y}$ & $\mathrm{y}$ & $?$ & - & $\mathrm{y}$ & 10 & HIGH \\
\hline Komeili et al. (2014) & $\mathrm{y}$ & $\mathrm{y}$ & $\mathrm{n}$ & $?$ & $\mathrm{y}$ & $\mathrm{y}$ & $\mathrm{y}$ & $\mathrm{y}$ & $\mathrm{n}$ & $?$ & $?$ & $?$ & - & $\mathrm{y}$ & 7 & MOD \\
\hline Parent et al. (2014) & $\mathrm{y}$ & $\mathrm{y}$ & $\mathrm{y}$ & $?$ & $\mathrm{y}$ & $\mathrm{y}$ & $\mathrm{y}$ & $\mathrm{n}$ & $\mathrm{n}$ & $?$ & $\mathrm{y}$ & $?$ & - & - & 7 & MOD \\
\hline Glinkowski et al. (2014) & $\mathrm{y}$ & $\mathrm{y}$ & $\mathrm{y}$ & - & $\mathrm{y}$ & $\mathrm{y}$ & - & $\mathrm{y}$ & $\mathrm{y}$ & $?$ & - & $\mathrm{y}$ & - & $\mathrm{y}$ & 9 & $\mathrm{HIGH}$ \\
\hline Weiss et al. (2013) & $\mathrm{y}$ & $\mathrm{y}$ & $\mathrm{y}$ & - & $\mathrm{y}$ & $\mathrm{y}$ & $\mathrm{y}$ & $\mathrm{y}$ & $?$ & $?$ & - & - & - & $\mathrm{y}$ & 8 & MOD \\
\hline Fortin et al. (2013) & $\mathrm{y}$ & $\mathrm{y}$ & $\mathrm{y}$ & - & $\mathrm{y}$ & $\mathrm{y}$ & $\mathrm{n}$ & $\mathrm{y}$ & $\mathrm{y}$ & $?$ & $?$ & - & - & $\mathrm{y}$ & 8 & MOD \\
\hline Sagd et al. (2012) & $\mathrm{y}$ & $\mathrm{y}$ & $\mathrm{y}$ & $\mathrm{y}$ & $\mathrm{y}$ & - & $?$ & $\mathrm{y}$ & - & $\mathrm{y}$ & - & - & - & $\mathrm{y}$ & 8 & MOD \\
\hline Fortin et al. (2012) & $\mathrm{y}$ & $\mathrm{y}$ & $\mathrm{y}$ & $\mathrm{y}$ & $\mathrm{y}$ & $\mathrm{y}$ & $\mathrm{y}$ & $\mathrm{y}$ & - & $\mathrm{y}$ & - & - & - & $\mathrm{y}$ & 10 & $\mathrm{HIGH}$ \\
\hline Sarnadskiy (2012) & $?$ & $\mathrm{y}$ & $\mathrm{y}$ & - & $?$ & $\mathrm{y}$ & - & $\mathrm{n}$ & - & $?$ & - & - & - & $?$ & 3 & LOW \\
\hline Sarnadskiy (2012) & $\mathrm{y}$ & $\mathrm{y}$ & $\mathrm{y}$ & - & $?$ & $\mathrm{y}$ & - & $\mathrm{y}$ & - & $?$ & - & - & - & $\mathrm{y}$ & 6 & MOD \\
\hline Glinkowski et al. (2012) & $\mathrm{y}$ & $\mathrm{y}$ & $\mathrm{y}$ & - & $\mathrm{y}$ & $\mathrm{y}$ & $\mathrm{n}$ & $\mathrm{y}$ & $\mathrm{y}$ & - & - & $\mathrm{y}$ & - & $\mathrm{y}$ & 9 & $\mathrm{HIGH}$ \\
\hline Rankine et al. (2012) & - & - & $\mathrm{y}$ & - & $?$ & - & - & $?$ & - & $?$ & - & - & - & - & 1 & LOW \\
\hline Aroeira et al.(2011) & $\mathrm{n}$ & $\mathrm{y}$ & $\mathrm{y}$ & $\mathrm{y}$ & $\mathrm{y}$ & $\mathrm{y}$ & $\mathrm{y}$ & $\mathrm{y}$ & - & $\mathrm{y}$ & $\mathrm{y}$ & - & - & $\mathrm{y}$ & 10 & $\mathrm{HIGH}$ \\
\hline
\end{tabular}

Questions of the QUADAS tool: 1) Was the spectrum of patients representative of the patients who will receive the test in practice? 2) Were selection criteria clearly described? 3) Is the reference standard likely to correctly classify the target condition? 4) Is the time period between reference standard and index test short enough to be reasonably sure that the target condition did not change between the two tests? 5Did the whole sample or a random selection of the sample, receive verification using a reference standard of diagnosis? 6) Did patients receive the same reference standard regardless of the index test result? 7) Was the reference standard independent of the index test (i.e. the index test did not form part of the reference standard? 8) Was the execution of the index test described in sufficient detail to permit replication of the test? 9) Was the execution of the reference standard described in sufficient detail to permit its replication? 10) Were the index test results interpreted without knowledge of the results of the reference standard? 11) Were the reference standard results interpreted without knowledge of the results of the index test? 12) Were the same clinical data available when test results were interpreted as would be available when the test is used in practice? 13) Were uninterpretable/intermediate test results reported? 14) Were withdrawals from the study explained? Criteria answers: y/ yes; n/ no; ?/ unclear; - not applicable. 